\title{
GENEZA POSADZKI PAŁACOWEJ - ZABYTKOWEJ WARSTWY WYKOŃCZENIOWEJ
}

\author{
Katarzyna Kafel ${ }^{\bowtie}$, Piotr Buda \\ Wydział Inżynierii Lądowej, Politechnika Krakowska
}

\begin{abstract}
STRESZCZENIE
Podłoga jest elementem budynku mającym na celu wykończenie przegród poziomych, nadanie im właściwości użytkowych i estetycznych. Posadzki drewniane są częstym elementem wykończeniowym podłóg obiektów budowlanych. Dzięki właściwościom fizycznym drewna takie rozwiązanie gwarantuje komfort użytkownikom podłóg. Renowacja zabytkowych posadzek drewnianych charakteryzuje się znaczną specyfiką robót ze względu na potrzebę zachowania ich unikalnego charakteru. Celem pracy jest usystematyzowanie pojęć definiujących drewnianą warstwę wierzchnią podłóg zabytkowych oraz wykonywanych współcześnie. W artykule omówiono przykłady renowacji posadzki zabytkowej oraz realizacji posadzki wykonywanej od podstaw, które posłużyły jako zobrazowanie terminologii i różnic między pałacową zabytkową mozaiką a wykonywaną współcześnie. Analiza literatury pod względem terminologii związanej z posadzkami drewnianymi pozwoliła unaocznić różnice w wykonawstwie warstw wierzchnich podłóg. W pracy przedstawiono również genezę powstania terminu ,posadzka pałacowa” oraz jego współczesną interpretację.
\end{abstract}

Słowa kluczowe: posadzka pałacowa, mozaika, parkiet, posadzka drewniana, podłoga zabytkowa

\section{WSTĘP}

Posadzki drewniane są częstym elementem wykończeniowym podłóg obiektów budowlanych. Ze względu na właściwości fizyczne drewno stosuje się jako materiał wykończeniowy, gdyż wprowadza aspekt komfortu podczas użytkowania podłogi.

Renowacja zabytkowych posadzek drewnianych charakteryzuje się znaczną specyfiką robót, zachowującą ich unikalny charakter. Proces odrestaurowania posadzek drewnianych oraz wykonywanie posadzek drewnianych od podstaw wymaga dużego nakładu pracy oraz środków pieniężnych, a precyzyjność, doświadczenie oraz umiejętności manualne są niezbędne przy pracy z zabytkowym materiałem i podczas jego obróbki. Równie ważnym aspektem jest odpowiedni dobór materiałów przeznaczonych do mocowania, okresowa konserwacja i pielęgnacja w późniejszym okresie eksploatacji. Wszelkie utrudnienia pojawiąjące się w trakcie renowacji mogą zostać wyeliminowane dzięki wcześniejszym, dokładnym badaniom historycznym, doświadczeniu oraz umiejętności osób wykonujących remont. Wykonanie posadzki drewnianej od podstaw wymaga znacznie większego nakładu środków materiałowych niż w przypadku renowacji, przy równie dużym nakładzie prac ze względu na skomplikowany cykl produkcyjny. W wykonawstwie i konserwatorstwie drewnianych posadzek powinno stosować się nowoczesne technologie, jednocześnie dbając o zachowanie ich historycznego wizerunku.

Problem renowacji i technologii wykonywania podłóg drewnianych jest tematem wielu krajowych i zagranicznych publikacji naukowych. Pojawia się w nich terminologia określająca zarówno układ warstw 
podłóg, jak i nazewnictwo związane z poszczególnymi jej częściami składowymi. Przegląd projektów podłóg drewnianych w obiekcie zabytkowym zawarty jest w pracy Swaczyny, Kędzierskiego, Różańskiej, Szymczyk, Tomusiaka, Rżewskiej (2010). Autorzy opisują charakterystykę podłogi pod względem elementów tworzących jej konstrukcję, a także odmian drewna i jego włókien w warstwie wierzchniej. Publikacja Raposo, Andradego, Correi i De Jesusa (2018) to studium przypadku zabytkowego średniowiecznego budynku jako analiza jego drewnianej podłogi pod względem stanów granicznych użytkowalności oraz sposobów jej konserwacji. Diagnostyka drewna jako jednego $\mathrm{z}$ materiałów konstrukcyjnych podłogi została omówiona w pracy Delgado, de Brita i Silvestrego (2013) poprzez analizę jego wad wpływających bezpośrednio na właściwości warstwy wykończeniowej. Artykuł Delgado i współautorów (2013) ukazuje przypadek ze zlokalizowanymi defektami, zawierający pełną charakterystykę, przyczyny powstania, najbardziej odpowiednie metody diagnostyczne oraz techniki naprawcze. Prawidłowe wykonanie oraz renowacja posadzek drewnianych wymaga znajomości ich właściwości technicznych oraz cech, jakie musza mieć, aby prawidłowo spełniały swoje funkcje (Merritt i Ricketts, 2000). Rodzaje posadzek dla budownictwa mieszkaniowego, w tym posadzki drewniane, opisuje praca Nowobilskiego i Hoły (2017). Autorzy wykonali klasyfikację warstwy wykończeniowej pod względem zastosowanego materiału, uwzględniając tradycyjne i nowoczesne rozwiązania. Zainteresowanie tematem posadzek drewnianych na płaszczyźnie innych dziedzin nauki potwierdza, jak znaczącą rolę odgrywa warstwa wykończeniowa w obiektach budowlanych. Podstawowe definicje, terminologia oraz podział posadzek jako wierzchniej warstwy podłogi zawarte są w artykule Gaczka i Fiszera (2010). Podział uwzględnia specyfikę warunków eksploatacji, które są odmienne ze względu na poszczególne wymagania użytkowe dla posadzek $\mathrm{w}$ budownictwie ogólnym: mieszkaniowym, użyteczności publicznej, przemysłowym, rolniczym, sanitarnym itd.

Celem pracy jest usystematyzowanie pojęć definiujących drewnianą warstwę wierzchnią podłóg zabytkowych oraz wykonywanych współcześnie. Motywem artykułu zostało pytanie zadane na konferencji naukowej dotyczące wyjaśnienia terminu ,posadzka pałacowa" podczas prezentacji referatu na temat analizy technologicznej prac remontowych drewnianych podłóg pałacowych. W celu zobrazowania terminologii i różnic między mozaiką zabytkową a współczesną omówiono przykłady renowacji starych i realizacji nowych drewnianych posadzek. Na podstawie literatury przedmiotu wykonano analizę rozbieżności wspomnianych wcześniej terminów. Istnieje potrzeba usystematyzowania pojęć z zakresu nazewnictwa podłóg drewnianych, co pozwoli wykluczyć niejasności w procesie wykonawstwa oraz renowacji drewnianych elementów wchodzących w skład konstrukcji podłogi.

\section{TERMINOLOGIA Z ZAKRESU KONSTRUKCJI PODŁOGI}

Podłoga jest elementem budynku mającym na celu wykończenie przegród poziomych, nadanie im właściwości użytkowych i estetycznych. Jej podstawowym zadaniem jest przenoszenie obciążeń dynamicznych oraz statycznych (Wolski, 1998). Podłoga z reguły składa się z kilka warstw (rys. 1): użytkowej, jastrychu (ewentualnie z podkładem), rozdzielczej, izolacyjnej przeciwwilgociowej i ocieplającej (thumiącej). Rodzaj, grubość i układ poszczególnych warstw są uzależnione od wymagań ochrony wilgotnościowej, dźwiękowej oraz cieplej (Neufert, 2011). Konstrukcje podłogowe można podzielić na kilka podstawowych schematów, a także według zastosowanych podkładów, co przedstawia tabela (s. 45).

Według nomenklatury budowlanej wierzchnią warstwą podłogi nazywamy posadzką i stanowi ona jej zewnętrzne wykończenie. Posadzki występują we wszystkich rodzajach podłóg wewnętrznych i zewnętrznych. Są one jednym z najbardziej eksponowanych elementów wykończeniowych budynków ze względu na znaczny wpływ architektonicznego kształtowania wnętrza oraz zapewnienie właściwych warunków użytkowania danego pomieszczenia. Kwestia wyboru konkretnego materiału posadzki, oprócz możliwości finansowych inwestora, podyktowana jest wieloma względami (Gaczek i Fiszer, 2010). Określenie preferencji architektów dotyczących wyboru rodzaju podłogi zostało przeanalizowane $\mathrm{w}$ artyku- 
Rys. 1. Układ warstw podłogi dla stropów między kondygnacjami mieszkalnymi (Neufert, 2011)

Fig. 1. Sequence of floor layers for ceilings between residential floors (Neufert, 2011)

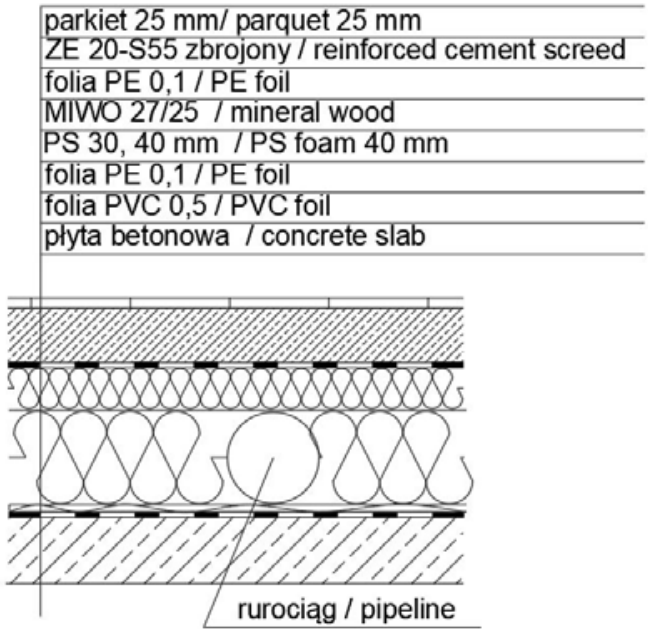

Tabela. Rodzaje konstrukcji podłogowej oraz podkładów (Wolski, 1998)

Table. Types of floor construction and screeds (Wolski, 1998)

\begin{tabular}{ll}
\hline Klasyfikacja & \\
\hline & - podłogi na gruncie \\
& - podłogi z izolacją cieplną \\
& - podłogi z izolacją przeciw dźwiękową \\
& - podłogi wodoszczelne \\
& - podłogi o podwyższonych właściwościach sprężystych \\
Rodzaje konstrukcji podłogowej & - podłogi o podwyższonych właściwościach mechanicznych \\
& - podłogi o podwyższonej odporności chemicznej \\
& - podłogi o obniżonych wymaganiach technicznych i estetycznych \\
& - podłogi z instalacją ogrzewania podłogowego \\
\hline & - podkład związany z podłożem \\
Podział podkładów podłogowych & - podkład oddzielony od podłoża przekładką rozdzielającą \\
ze względu & - podkład pływający \\
na powiązanie z podłożem & - podkład grzewczy \\
& - podkład podniesiony \\
& - podkład deskowy \\
\hline & - podkłady monolityczne \\
Podział podkładów podłogowych & - jastrychy zewnętrzne \\
ze względu & - podkłady prefabrykowane \\
na zastosowany materiał & - podkłady prefabrykowane lekkie \\
& - podkłady izolacyjne \\
\hline
\end{tabular}

le Macias i Knowlesa (2011). Treść Rozporządzenia Ministra Infrastruktury z dnia 12 kwietnia 2002 r. w sprawie warunków technicznych, jakim powinny odpowiadać budynki i ich usytuowanie (Dz.U. 2002 nr 75, poz. 690 z późn. zm.), zawiera kryteria wyboru, które umożliwiają podjęcie decyzji o zastosowanym rodzaju materiału. Są to między innymi: przeznaczenie pomieszczenia i sposób jego użytkowania, właściwości cieplne (izolacyjność cieplna, aktywność cieplna związaną z ciepłem dotyku), odporność na ścieranie, twardość, antypoślizgowość, gładkość powierzchni, odporność na działanie ognia, wytrzymałość na wpływy mechaniczne, pochłanianie dźwięków, odporność na działanie związków chemicznych, łatwość utrzy- 
mania w czystości, odporność na przenikanie wody, walory estetyczne oraz spełnienie odpowiednich wymagań higienicznych i prawnych.

\section{CHARAKTERYSTKA I PODZIAŁ POSADZEK DREWNIANYCH}

Podłogi drewniane charakteryzuje wiele zalet, takich jak: uniwersalność i naturalny charakter, izolacyjność cieplna czy odnawialność powierzchni. Wykonywane są z desek lub bali świerkowych, sosnowych i jodłowych. Ze względu na dużą wytrzymałość mechaniczną najczęściej wybieranym gatunkiem drzewa jest sosna. Drewno świerkowe ma znaczną liczbę sęków, z kolei jodłowe jest giętkie i łupliwe. Najprostszymi podłogami drewnianymi są podłogi jednowarstwowe $\mathrm{z}$ desek, które są przybijane bezpośrednio do belek stropowych lub legarów, a w podłogach dwuwarstwowych ślepa podłoga jest pierwszą warstwa i stanowi podkład dla podłogi właściwej, czyli posadzki. W tej warstwie wymagana jest szczelność ułożenia elementów, co zapewniaja łączenia na półwpust, na wpust i pióro obce lub na wpust i pióro własne $\mathrm{z}$ wymaganym przybiciem do podkładu lub przytwierdzeniem klejem (Korobczak, 2006). Do wykonania posadzek drewnianych powszechnie były wykorzystywane gatunki drewna iglastego oraz liściastego: sosna pospolita, buk, jesion oraz dąb. Coraz większą popularność od kilkunastu lat zyskują gatunki drewna egzotycznego ze względu na dużą odporność na ścieranie, uszkodzenia i zarysowania oraz bogatszą kolorystykę (Kozakiewicz, Noskowiak i Pióro, 2012). Drewno egzotyczne jest materiałem dla elementów posadzkowych wszystkich wymiarów, takich jak: deski, klepki parkietowe i mozaikowe, panele laminowane, płyty OSB i wiórowe, mające budowę warstwową (Gaczek i Fiszer, 2010). Norma w zakresie parkietów (PN-EN 13226:2009. Podłogi drewniane. Elementy posadzkowe lite z wpustami i/lub wypustami) obowiązuje w Polsce od 2004 roku i zawiera listę gatunków drewna najczęściej wykorzystywanych do produkcji posadzek drewnianych, opis gatunków drewna europejskiego i egzotycznego wraz z charakterystyką ich barw i odcieni, a także opis wpływu światła po pewnym czasie ich ekspozycji w miejscach niezacienionych. Parkiet jako warstwa wykończeniowa podłogi może występować w formie deszczułek, gotowych płyt mozaikowych oraz desek parkietowych. Innym rodzajem drewnianego wykończenia podłogi są kostki brukowe produkowane $\mathrm{z}$ dębowego drewna czołowego, o kształcie kwadratowym bądź okrągłym, układane na podłożu betonowym (Neufert, 2011). Posadzki mozaikowe jako rodzaj współcześnie wykonywanych wykładzin podłogowych oprócz drewna mogą być wykonane także z kamienia, ceramiki oraz ze szkła. Mozaika jest posadzką układaną z bardzo krótkich, wąskich drewnianych deszczułek, których kształt jest ściśle określony, co gwarantuje otrzymanie pożądanego wzoru po ułożeniu. Drewniane płyty mozaikowe są wykonywane $\mathrm{z}$ tych samych gatunków drewna co deszczułki lite. Płyty są tworzone dzięki drobnym listewkom o grubości $6-10 \mathrm{~mm}$, które są przyklejone stroną licową do arkusza papieru (rys. 2). Ich układ może mieć postać szachownicy lub bardziej ozdobny (Wolski, 1998).

Prawidłowe wykonanie posadzki z płyt mozaikowych jest uwarunkowane bardzo dobrym przygotowaniem podłoża. Podłoga powinna zachowywać powierzchnię poziomą na całym obszarze, który zajmuje, a podkład betonowy nie może być pylący. Pomiar posadzki powinien nastąpić przez przyłożenie łaty kontrolnej $\mathrm{w}$ dowolnym miejscu pomieszczenia w dwóch prostopadłych do siebie kierunkach. Odchylenia od płaszczyzny, które można zauważyć przez prześwity pomiędzy łatą i podłogą, nie powinny wynosić więcej niż $2 \mathrm{~mm}$. Chcąc zwiększyć przyczepność warstwy kleju, należy rozcieńczyć zagruntowany podkład posadzki przed przystąpieniem do montażu. Rozprowadzany klej na podłożu powinien mieć większą szerokość od płyt mozaikowych, a kierunek układania rzędów należy wytyczyć za pomocą sznura przytwierdzonego do podłoża. Płyty przykleja się zwilżonym wodą papierem do góry, po czym usuwa się go. Istnieją również rozwiązania posadzek mozaikowych posiadających spodnią warstwę listewek naklejoną na stałe na siatce, a następnie układaną w całości. Górna warstwa jest gotowa do użycia, gdyż została fabryczne wykończona. Dzięki temu rozwiązaniu montaż jest szybki, ponieważ nie wymaga układania każdego kwadratu oddzielnie. Kierunek układania płyt powinien rozpoczynać się od ściany przeciwległej drzwiom wejściowym pomieszczenia, w którym następuje mocowanie posadzki (Wolski, 1998). 

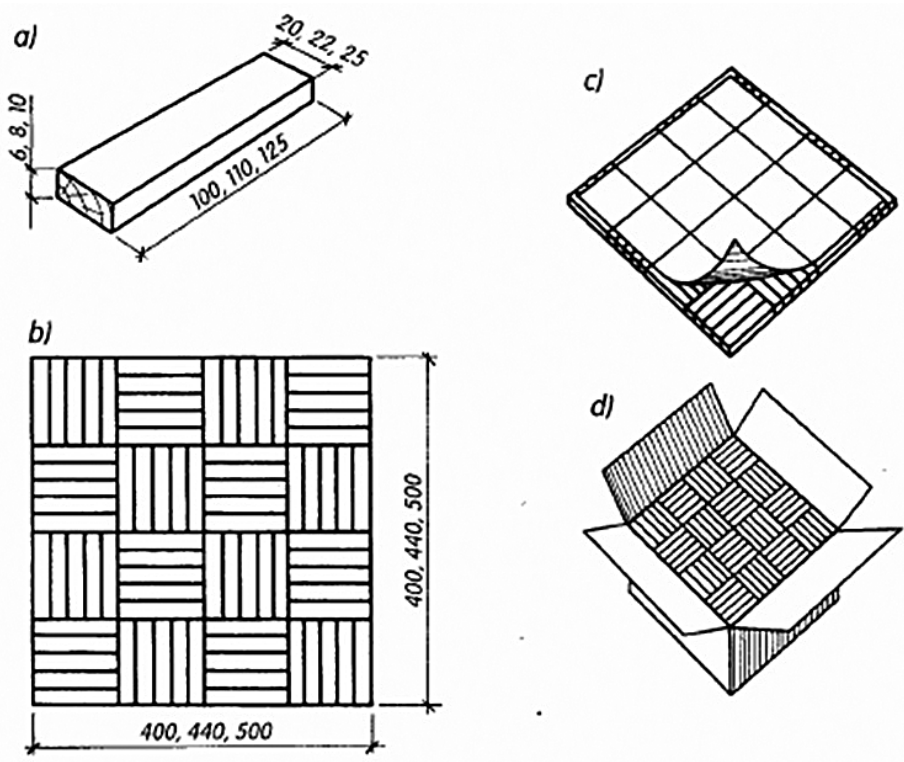

Rys. 2. Drewniane płyty mozaikowe: $\mathrm{a}$ - listewka; $\mathrm{b}$ - zestaw listewek tworzących płytę; $\mathrm{c}$ - płyta oklejona papierem; $\mathrm{d}$ - pudło tekturowe z płytami mozaikowymi (Wolski, 1998)

Fig. 2. Wooden mosaic tiles, where: $\mathrm{a}-\mathrm{a}$ slat; $\mathrm{b}-\mathrm{a}$ set of slats forming a plate; $\mathrm{c}-\mathrm{a}$ board covered with paper; $\mathrm{d}-\mathrm{a}$ cardboard box with mosaic panels (Wolski, 1998)

\section{GENEZA POSADZKI PAŁACOWEJ JAKO ZABYTKOWEJ WARSTWY WYKOŃCZENIOWEJ}

Chcąc zdefiniować pojęcie posadzki pałacowej, należy zapoznać się $\mathrm{z}$ historią rozpoczęcia produkcji drewnianej warstwy wykończeniowej podłogi. Geneza terminu ,parkiet” wywodzi się od królewskiego bądź sędziowskiego określenia podwyższenia tronowego. Od XVII wieku definiowano tym pojęciem grube płyty taflowe mocowane do legarów, a ich prostota doskonale komponowała się z kanonami średniowiecznej architektury. Okres ten zapoczątkował erę parkietu taflowego, który został wyparty dopiero przez lite deszczułki drewniane, dzisiaj znane jako posadzka parkietowa. Średniowieczna posadzka parkietowa $\mathrm{z}$ bali ciosanych była układana w najbardziej reprezentatywnych miejscach budynku, renesans natomiast rozszerzył popularność drewnianego wykończenia podłogi dzięki walorom akustycznych oraz możliwości tworzenia efektownych aranżacji, które mogły w znaczący sposób podkreślić hierarchię społeczną oraz stan finansowy właściciela. Parkiety taflowe spełniały znaczącą funkcję w pałacach oraz zamkach jako jeden $\mathrm{z}$ ważniejszych elementów wystroju wnętrz. Wykonanie tak ozdobnej podłogi było kosztowym i pracochłonnym przedsięwzięciem. Realizacja najbardziej okazałych i reprezentatywnych posadzek przez zespoły mistrzów oraz czeladników trwała nawet 10 lat, pochłaniając duże ilości nakładu pracy i kosztów. Przez lata występowanie dekoracyjnych parkietów stawało się coraz bardziej powszechne, zdobiły one wnętrza pałaców, ekskluzywnych hoteli, obiektów rodów szlacheckich, mieszczańskich oraz sakralnych. Pod koniec XIX wieku zaczęto stosować nowy produkt - deszczułkę parkietową. Wytwarzanie jej przez wyspecjalizowane fabryki pozwalało obniżyć koszty produkcji, co spowodowało większą dostępność parkietu, a zarazem mniejszy popyt na ręcznie tworzone tafle parkietowe przez mistrzów stolarskich (Fawcett, 2001). Obecnie parkiety taflowe spotyka się w obiektach lub pomieszczeniach pełniących funkcje reprezentacyjne, a deszczułki parkietowe stosuje się przy realizacji posadzek w niskobudżetowych inwestycjach budowlanych.

Wraz z rozwojem produkcyjnym posadzek powstały różne rodzaje deszczułek parkietowych, a wśród nich popularna i niedroga mozaika parkietowa imitująca parkiety taflowe układane w obiektach pałacowych (Kuczyńska-Cichocka, 2010). Współcześnie mianem 
Kafel, K., Buda, P. (2019). Geneza posadzki pałacowej - zabytkowej warstwy wykończeniowej. Acta Sci. Pol. Architectura, 18 (4), 43-50. doi: 10.22630/ASPA.2019.18.4.44

posadzki pałacowej nazywa się mozaikę odznaczającą się szczególnie eleganckim i zdobiącym wnętrze wzorem, co według autorów jest błędnym zastosowaniem tego terminu. Nawiązuje ona silnie pod względem estetyki do wzorów tradycyjnych, które były obecne w budownictwie pałacowym minionych epok. Obecnie istnieje wielu producentów drewnianych posadzek korzystających z renomy tafli pałacowych, którzy określają tym terminem produkty tworzone na ich wzór, a są nimi różnokierunkowe układy deszczułek parkietowych (rys. 3).

Prace z posadzkami pałacowymi najczęściej wykonywane są $\mathrm{w}$ trakcie remontów obiektów zabytko- wych lub reprezentacyjnych obiektów publicznych. Przykładem przeprowadzonego procesu odrestaurowania posadzki zabytkowej jest klasztoru oo. Bernardynów w Kalwarii Zebrzydowskiej. Po wstępnych oględzinach przeprowadzonych na miejscu stwierdzono znaczne zniszczenie i przetarcia lakieru na całej powierzchni pomieszczania. Efekt renowacji posadzki został przedstawiony na rysunku $4 \mathrm{~b}$.

Oprócz procesów remontowych posadzka pałacowa współcześnie często staje się przedmiotem inwestycji wykonywanej od początku. Proces wytwarzania mozaiki pałacowej zawsze był uznawany za pracę rzemieślniczą. Pomimo rozwojowi fabrycznej technolo-
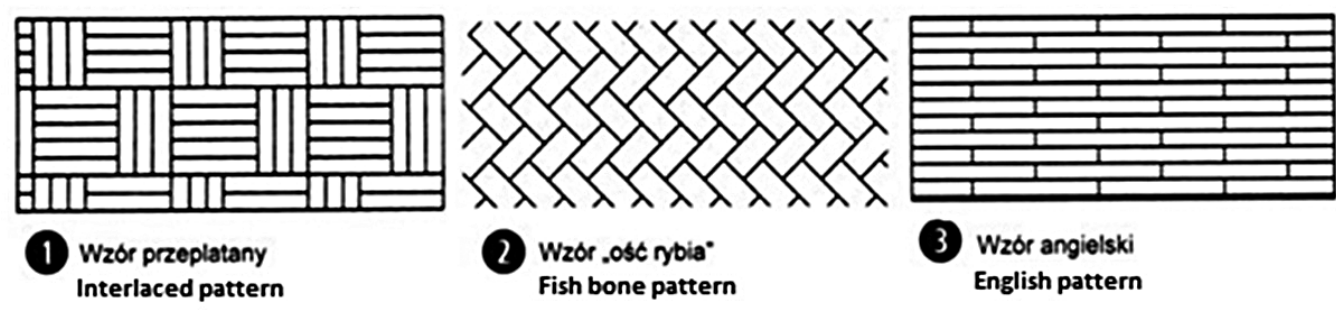

Fish bone pattern

(3) Wzor angielski English pattern
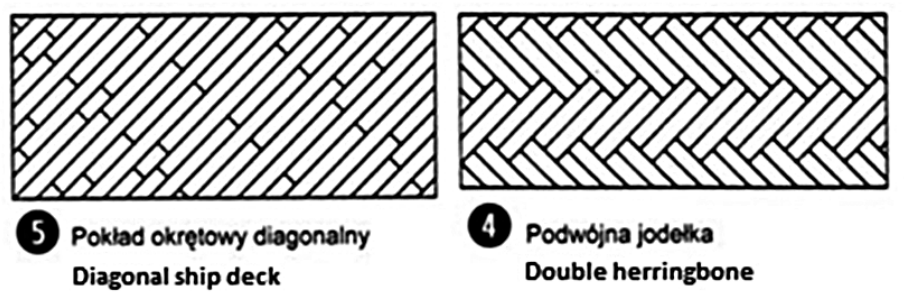

(4) Poowojna jodetka

Double herringbone

Rys. 3. Wzory układane z deszczułek parkietowych (Neufert, 2011)

Fig. 3. Patterns laid out of parquet slats (Neufert, 2011)

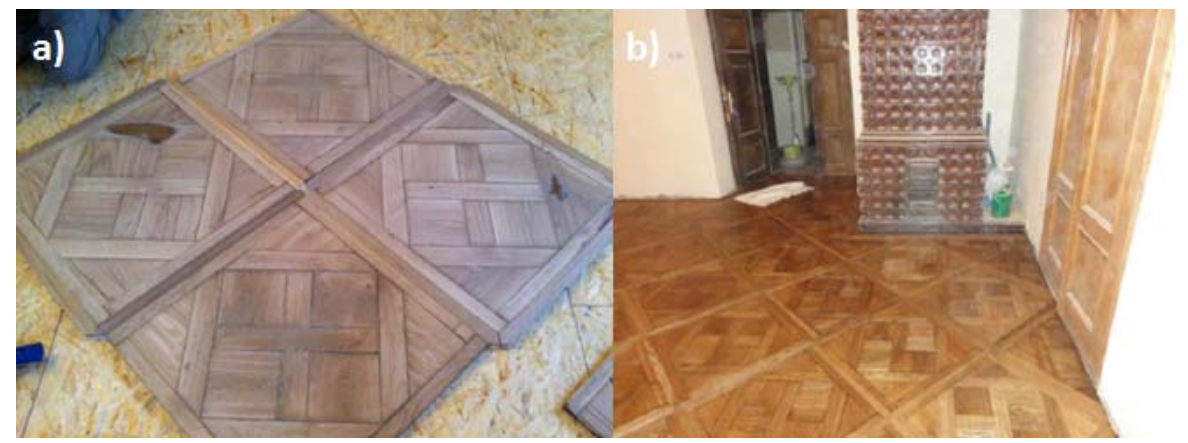

Rys. 4. Zabytkowa posadzka w klasztorze oo. Bernardynów w Kalwarii Zebrzydowskiej: a - tafle pałacowe przygotowane do renowacji; b - efekt po realizacji

Fig. 4. Historic floor in the Bernardine monastery in Kalwaria Zebrzydowska: a - palace panels prepared for restoration; $\mathrm{b}$ - after effect 


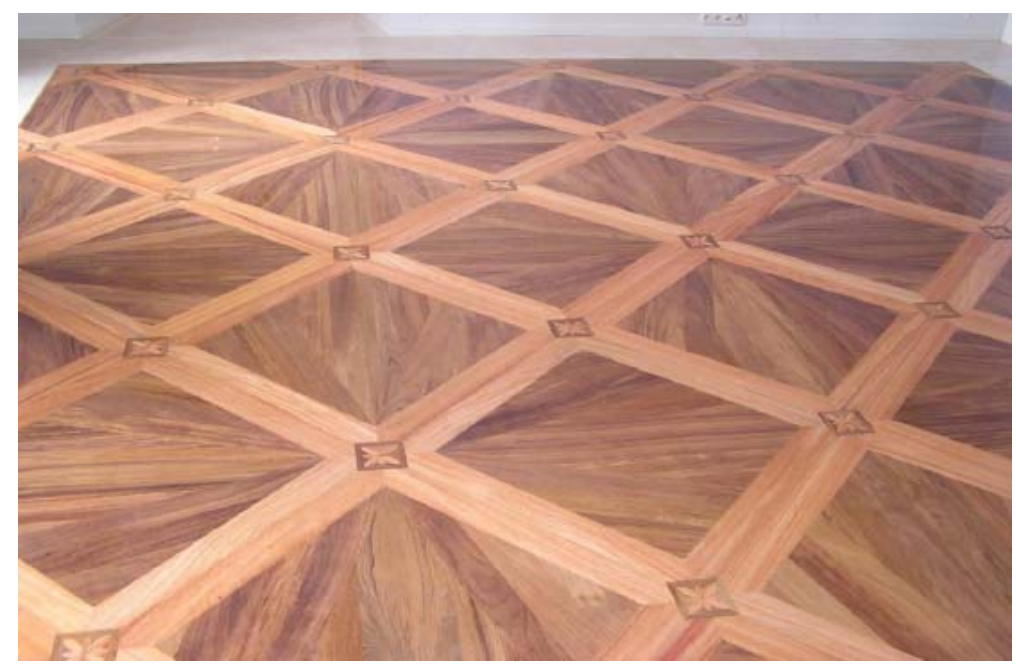

Rys. 5. Posadzka pałacowa wykonana od podstaw

Fig. 5. Palace floor made from scratch

gii wykonywania podłóg drewnianych posadzki nadal wykonuje się manualnie, choć już tylko częściowo. Po wybraniu przez inwestora odpowiedniego wzoru podłogi pałacowej następuje pozyskanie elementów składowych każdej tali. Pojawienie się na rynku maszyn obróbczych CNC (z ang. computerized mumerical control) do drewna pozwoliło na uzyskiwanie kształtów geometrycznych, które tworzą oryginalne i tradycyjne wzory. Mechanizacja pracy wytwarzania posadzki skutkuje zaoszczędzonym czasem, a także obniża koszty produkcji. Jednak długotrwała produkcja tafli w warunkach rzemieślniczych pozwala na jej unikalny charakter, co może potwierdzać stałe zainteresowanie ze strony inwestorów na ręcznie wykonywane posadzki pałacowe. Rysunek 5 ukazuje wykonaną od podstaw posadzkę pałacową za zamówienie prywatnego inwestora. Elementy taflowe, elementy wewnętrzne, ramki łączące oraz wstawki w postaci dekorów zostały wcześniej przygotowane $\mathrm{w}$ warsztacie, następnie połączono je podczas bezpośredniego układania na budowie.

\section{PODSUMOWANIE}

Ze względu na wiele zalet drewna jako surowca do produkcji warstw wykończeniowych podłóg, pomimo dostępności innych alternatywnych rozwiązań, drewno jest jednym z najczęściej wybieranych materiałów do wykonania posadzek. Nawiązanie do tradycji oraz architektury renesansowej pozwala zastosować wyrób bogato zdobiący wnętrza, jakim są mozaiki parkietowe współcześnie tworzone na wzór posadzek pałacowych. Obecnie wielu producentów przypisuje nazewnictwo posadzki pałacowej drewnianym parkietom układanym na wzór jodełki, szachownicy, przeplatanki lub kwadratów z mniejszymi elementami wykonanymi z różnych gatunków drewna. Opisane zastosowanie nazewnictwa jest według autorów niepoprawne, gdyż niejednokrotnie może spowodować niejasności w trakcie procesu wykonawczego, w szczególności podczas renowacji zabytkowych warstw wykończeniowych podłóg. Zgodnie z Ustawą z dnia 23 lipca 2003 r. o ochronie zabytków i opiece nad zabytkami (Dz.U. 2003 nr 162, poz. 1568 z późn. zm.) pracami renowacyjnymi przy obiektach wpisanych do rejestru zabytków mogą kierować osoby mające wykształcenie oraz uprawnienia $\mathrm{w}$ zakresie wykonywanych robót oraz posiadające doświadczenie $\mathrm{w}$ pracach konserwatorskich. W przypadku obiektów z posadzką pałacową, które nie są uwzględnione w rejestrze zabytków, inwestor może prowadzić prace przy udziale przypadkowych firm, których pracownicy często nie mają wystarczającej wiedzy, uprawnień i doświadczenia $\mathrm{w}$ obrębie danego rodzaju robót. W konsekwencji oryginalne posadzki pałacowe mogą być zastąpione panelami, płytkami ceramicznymi lub wykładzina- 
mi. Przedstawione w artykule przykłady renowacji posadzki zabytkowej oraz wykonania nowej, a także analiza literatury pod względem terminologii $\mathrm{z}$ zakresu posadzek drewnianych pozwoliły zobrazować różnice w wykonawstwie warstw wierzchnich podłóg. Przedstawiono genezę powstania terminu „posadzka pałacowa" oraz współczesną jego interpretację, którą posługuje się wielu wykonawców reklamujących swoje usługi. Zaprezentowane przykłady zrealizowanych posadzek unaoczniły, że renowacja oraz wykonanie tafli pałacowych należą do prac budowlanych wymagających precyzji, czasu oraz doświadczenia.

\section{PIŚMIENNICTWO}

Delgado, A., de Brito, J. i Silvestre, J. D. (2013). Inspection and Diagnosis System for Wood Flooring. Journal of Performance of Constructed Facilities, 27 (3), 564-574.

Fawcett, J. (2001). Historic Floors. Their History and Conservation. Oxford: Butterworth-Heinemann.

Gaczek, M. i Fiszer, S. (2010). Posadzki w budownictwie ogólnym. Część 1. Definicje i podział. Builder, 1, 66-67.

Korobczak, A. (2006). Wykonywanie podtóg z gotowych elementów drewnianych. Radom: Instytut Technologii Eksploatacji - Państwowy Instytut Badawczy.

Kozakiewicz, P., Noskowiak, A. i Pióro, P. (2012). Atlas drewna podtogowego. Warszawa: Profi-Press.

Kuczyńska-Cichocka, M. (2010). Od pnia do deszczułki, czyli jak produkuje się parkiet. Profesjonalny Parkiet, 1,51 .
Macias, M. i Knowles, C. (2011). Examining the effect of environmental certification, wood source, and price on architects' preferences of hardwood flooring. Silva Fennica, 45 (1), 97-109.

Merritt, S. F. i Ricketts, J. T. (2000). Building Design and Construction Handbook. New York: McGraw-Hill Professional.

Neufert, E. (2011). Podręcznik projektowania architektoniczno-budowlanego. Warszawa: Arkady.

Nowobilski, T. i Hoła, B. (2017). Bardziej i mniej znane posadzki budownictwa mieszkalnego. Builder, 21 (3), $84-87$.

PN-EN 13226:2009. Podłogi drewniane. Elementy posadzkowe lite $\mathrm{z}$ wpustami i/lub wypustami.

Raposo, P., Andrade, M., Correia, J. A. F. O. i De Jesus, A. M. P. (2018). Numerical analysis and structural intervention methodology for a wood floor of a medieval building. International Journal of Structural Integrit, 9 (3), 355-380.

Rozporządzenie Ministra Infrastruktury z dnia 12 kwietnia 2002 r. w sprawie warunków technicznych, jakim powinny odpowiadać budynki i ich usytuowanie. Dz.U. $2002 \mathrm{nr} 75$, poz. $690 \mathrm{z}$ późn. zm.

Swaczyna, I., Kędzierski, A., Różańska, A., Szymczyk, A., Tomusiak, A. i Rżewska, Z. (2010). Designs of wooden floorings in historical buildings in the Kolbuszowa County. Annals of Warsaw University of Life Sciences - SGGW. Forestry and Wood Technology, 72, 303-307.

Ustawa z dnia 23 lipca 2003 r. o ochronie zabytków i opiece nad zabytkami. Dz.U. 2003 nr 162, poz. 1568 z późn. zm.

Wolski, Z. (1998). Roboty podtogowe i okładzinowe. Warszawa: WSiP.

\section{ORIGIN OF PALACE FLOOR - HISTORIC FLOORING}

\section{ABSTRACT}

The floor is an element of the building aimed at finishing horizontal partitions, giving them utility and aesthetic properties. Wooden floors are a frequent finishing element of building floors. The use of wood as a finishing element is intended to introduce user comfort due to the physical properties of the material. Renovation of historic wooden floors is characterized by considerable specificity of works, due to the need to preserve their unique character. The aim of the work is to systematize the terminology that define the wooden top layer of historic and contemporary floors. The work also discusses the implementation of renovation of historic floor and made from scratch, which served as examples illustrating the terminology and differences associated with the historic palace mosaic, and the wooden floor made today. Analysis of the literature in terms of terminology within wooden floors, allowed to illustrate the differences in the performance of the top layers of floors. The work shows the origin of the term "palace floor" and its contemporary interpretation.

Key words: palace floor, mosaic, parquet, wooden floor, historic floor 